\title{
Macapat Al-Qur'an: Religious Literature and Oral Tradition in Rural Java
}

\author{
Roch Aris Hidayat ${ }^{1, *}$ \\ ${ }^{1}$ Badan Riset dan Inovasi Nasional, Indonesia \\ "Corresponding author. Email: masarishidayat@gmail.com
}

\begin{abstract}
This study describes a Javanese literary work nuanced in Islamic art entitled Macapat Al-Qur'an. This literary work is in the form of a macapat song. This literary work was composed based on the translation of the Al-Qur'an. The macapat song for the Javanese people is a work of art that has been very popular for a long time, but today's millennial generation, many don't know it, let alone sing it. This study wants to reveal the Macapat of the Al-Qur'an from various perspectives to be understood by the public, especially the millennial generation. This study uses a qualitative descriptive method with data collection techniques using interviews, observations, document studies, and focus group discussions (FGD). The results showed that the Macapat Al-Qur'an viewed from the perspective of fiqh does not conflict with Islamic teachings. Therefore, it is beneficial to instill moderate socio-religious values for students from an educational perspective. Viewed from the perspective of cultural arts, it can positively contribute to strengthening Islamic moderation through cultural arts. In addition, when viewed from a tourism perspective, it can inspire the birth of local culture-based art groups that support tourism development.
\end{abstract}

Keywords: Macapat, Al-Qur'an, arts and culture, Islam, moderation

\section{INTRODUCTION}

Culture results from human work that develops are owned and passed down from generation to generation. Culture has diverse elements, including language, knowledge systems, social systems or social organizations, living equipment systems and technology, livelihood systems, religious systems, and the arts. Art and religious systems are elements of culture that are not separate but are interrelated and mutually support one another. One form of culture that contains elements of art and a religious system, which is the object of this research, is the macapat song composed from the translation of the Al-Qur'an.

Historically it has been known that Walisongo carried out Islamic da'wah through cultural arts. For example, Walisongo created art tools and instruments in gamelan and songs to spread Islam to the community. In this context, at least two aspects are of concern to Walisongo so that the community can accept Islam, the majority of whom are Hindus. The two aspects are religion and cultural arts. Religion is the core of Walisongo's da'wah material, while art is an instrument in carrying out da'wah. It was done by walisongo because they understand that Javanese people generally really like art.

In a broader context, the discussion of religion and arts and culture can be seen in the relationship between religion and society. Religion and society in its development influence each other. Religion affects society, and society influences religion, so there is a dynamic interaction between the two. The dynamic interaction between religion and society takes place over a long period and reaches various world regions, including Indonesia. East Java is one of the provinces in Indonesia where the majority of the people are Muslim. In the Muslim community of East Java, a cultural product was born in the form of Islamic religious art. It was due to the interaction between religion and the religion's community.

Magetan is one of the districts in East Java that is rich in Islamic religious arts. Islamic religious arts in the area are pretty diverse. They have developed along with the dynamics of the interaction between Islam and Javanese culture, which has been intensifying since ancient times. The development of Islamic religious art in Magetan always experiences ups and downs and the development of the community's 
religious spirit [1]. It can be seen, among other things, from the number of art groups in Magetan that experience ups and downs. So, the development of Islamic religious art is intertwined with the religious spirit of the community. The development of art and the increasingly complex dynamics of society require continuous innovation from the community, especially the millennial generation, so that cultural arts remain sustainable and are in demand by the wider community and contribute to strengthening the nation's economy.

When Islamic religious art first entered East Java, data has not been obtained for sure. Some argue that it is estimated that various Islamic arts and cultures in East Java began to exist and develop during the Walisongo era and the birth of Islamic kingdoms in Java. Another opinion states that Islamic art and culture in East Java has existed since the arrival of the Arabs in Muslim enclaves in East Java, long before the time of Walisongo. However, these various opinions are not supported by solid evidence.

The presence of Islam in Java gave its color to the arts and culture in Java at that time. Islamic religious principles state that Islam respects various human creations, as long as they align with Islamic guidelines or signs. Cultural arts that contain noble values ( $m a^{\prime} r u f$ ) are community culture in line with Islamic signs. Meanwhile, arts and culture that invite sin and immorality are contrary to Islamic teachings. Cultural arts that contain noble values need to be developed. On the other hand, cultural arts that contain sin and immorality need to be removed from the culture of that society. This principle underlies the birth of Islamic art in Java.

Al-Quran is the main guideline for Muslims to appreciate works of art or human culture, as long as the works of art or culture are under the principles of Islamic teachings. Even the Koran itself is the Supreme Art of the Creator, Allah. The language and literature of the Qur'an are so beautiful that even no poet can compose a poem that resembles it. Al-Quran also requires humans to use all the potential that has been given by Allah SWT to be creative and innovate, as explained by the Prophet Muhammad, that Allah is beautiful and loves beauty. These human creations were later known as Islamic art and culture.

Al-Quran is the revelation to Prophet Muhammad (PBUH) started with the word "Iqra". Prophet (PBUH) had implemented five principles of al-Quran teaching and learning, which his companions and the next generation follow until today [2]. The model consists of Tilawah (good and fluency recitation), Tafahum and Tafsir (knowing and understanding the meaning), Tatbiq (appreciate and implantation of the teaching in daily life), Tahfiz (memorizing some verses for practice and reciting during prayer), and Taranum (reciting al-Quran with a good voice and proper song) [3]. In this part of the Noh article, the main areas of discussion will be how the Qur'an is taught in the Muslim community in particular in their mosques, madrasas, and community centers and hence their method of teaching and then how the audience perceives it, i.e., the students, teachers and also parents. The study found that the teachers have been using a variety of strategies in implementing quranic teaching and learning; some teaching methods, such as conventional and others, reflect new methods taking into consideration the different abilities of the children. However, this style of teaching ignores the quality of recitation and teaching with the rules of Tajwid. This article will then lead to a conclusion, which will include some suggestions on how to improve the primary curriculum and how the Qur'an should be taught [3]

Islamic art and culture is the result of human creativity, taste, and initiative that respects beauty while at the same time respecting the principles of propriety and nobility according to Islamic teachings. The principles of decency and nobility are essential because, in this modern era, many works of art that are not worthy of being exposed to the general public are said to be beautiful art and culture. Many artists who make inappropriate works of art, such as paintings that reveal their aurat, are considered beautiful paintings. Likewise, films that show genitalia invite lust and commit adultery are increasingly rampant. Not only movies but many musical groups or singers present erotic spectacles, show off their genitals, and invite the audience's lust -- such as dangdut koplo, which is rife in the Pantura area. Ironically, this spectacle is actually in great demand by the public. In fact, what is even sadder is when minors can also enjoy these treats freely. It shows that the principles of propriety and the nobility of artistic values still do not receive serious attention from various parties, especially the government and society. So, the principles of decency and nobility in art need to be considered and developed by the government and society. In the development of arts and culture, Islam teaches the principles of propriety and nobility [4]. Islam teaches art not only for art alone but also for art that is useful and meaningful to instill decency and moral nobility in its people.

The fundamental problem that needs attention from researchers and the public is preserving Islamic religious art and culture. For this reason, it is necessary to explore data on the number and map of their distribution. Currently, data on the number of Islamic 
arts and cultural groups in Magetan and a map of their distribution are not yet available accurately. Therefore, in the early stages of this research, it is necessary to carry out an inventory of Islamic religious art and culture, especially data on the number and distribution of Islamic art in Magetan.

This study is intended to determine the existence and characteristics of Islamic religious art in Magetan, especially the traditional art of tembang macapat, in contributing to religious moderation and to find out how far the development that has been carried out by the government and the community towards these Islamic religious art groups. This research proceeds to find a suitable model to guide Islamic religious arts groups in the area. Understanding the existence and characteristics of traditional macapat art is essential so that the training carried out is right on target. It is the reason why this research is essential and needs to be done.

Based on this background, the research problems studied can be formulated as follows, a) How is the history of the birth of the Islamic art of Macapat AlQur'an in Magetan, b) How is the existence of the art of the Macapat Al-Qur'an song in Magetan?, and c) How to build religious moderation through the art of the Macapat song Al-Qur'an?. The objectives to be achieved in this research area). Describes the history of the birth of the Islamic art of Macapat Al-Quran, b) Describes the existence of the art of the song Macapat Qur'an in Magetan, and c) Describes how to build religious moderation through the art of the song Macapat Qur'an in Magetan Regency.

The results of this study are expected to be useful theoretically and practically. The theoretical benefit is that the results of this research can add to the scientific treasures regarding the development and preservation of Islamic religious art, especially the art of Macapat Qur'an. The practical benefits of this research can be used as material for policymaking by the government and the community to foster and preserve and develop Islamic religious arts, especially the art of the Macapat Koran song in Magetan Regency.

The theoretical framework used to analyze the research problem consists of cultural theory, art theory, and Islamic religious art. Islamic religious art is part of art, and art is an element of a culture. Culture is the overall knowledge, beliefs, values possessed by humans as social beings [5]. Culture always contains three critical aspects: (1) culture is transferred from one generation to another, where culture is seen as a social heritage or tradition. (2) culture is learned, not transferred from the genetic condition of the human body, (3) culture is shared and shared by the members of the community that support it.

Three aspects of culture, namely culture as a social tradition, culture, are studied, and culture is lived by the community, providing an understanding that culture is closely related to the values held by society. One of the values adopted by the community is the values of Islamic teachings. Therefore, aspects of culture based on Islamic teachings' values are called Islamic culture. The values of Islamic teachings are those that can guide and direct their people to get closer to God.

Islamic culture covers many fields, one of which is art. Art, in general, is everything (creative work), the result of human reason and mind with all its processes. Art is also an expression of one's soul then the result of that soul expression can develop into part of human culture. Islamic religious art is essentially a part of art. The nature of art is an expression of culture and human thought. Thus art is part of human culture.

Koentjaraningrat suggests that culture has three levels that interact with each other. The first level is in objects resulting from human intelligence and creation (artifacts and creation). The second level is values and ideologies, the rules, principles, norms, values, and morals that guide organizations and are the assets they seek to fulfill. The third level is the basic unconscious assumptions about the state of truth and reality, humanity, human relations with nature, relations between humans, the state of time, and the universe. Thus, the culture is divided into three forms: the cultural system, the social system, and elements of physical culture [6]. The three forms of culture are interrelated or even mutually influence one another. Culture is not static; whether there are influences from outside (foreign) elements or not, then culture will continually change-cultural changes along with human needs and the passage of time itself.

Art as part of human culture also manifests in three forms: the art system, the value system, and the physical elements of art. The art system includes all things related to art and beauty produced by humans. The value system in art relates to rules, principles, norms, values, and morals related to artistic activities. Finally, the elements of art are physically in the form of a set of equipment/instruments, sounds, images, and several works of art in the form of artifacts and human creations.

Based on the theoretical framework above, Islamic religious art is all creative works resulting from the expression of human reason and mind that contain beauty. It does not conflict with Islamic 
teachings and can increase the faith and piety of humans who enjoy them. Therefore, Islamic religious art is different from folk art in general.

The Magetan community has quite a lot and varied works of art, both in terms of form and type and the values contained in it. Art forms in Magetan can conceptually be categorized into two forms, namely Islamic art and folk art. Islamic art is the art that follows or is not against the teachings of Islam. Therefore, Islamic art can bring benefits, significantly to increase faith, righteousness, and the love of an art connoisseur to Allah, not the other way around, getting closer to lust or indulgence in lust.

The benchmark for whether art is included in the category of Islamic art or not can also be based on three essential elements, as stated by Mudjahirin Thohir, namely motivation (intentions), embodiment (artwork) itself, and the effects. If the motivation for the birth of art is only within the framework of getting closer to Allah, then when it is realized, it does not conflict with what was intended. The work's desired effect can influence the viewer towards the path of Allah. Therefore, the art is Islamic art [7].

Artworks for Muslims are manifested in various forms. Forms of performing arts such as dance, tambourine art, and others. The form of music and sound art, such as qasidah, keroncong, and various other Islamic musical arts. The forms of sound art include the sound of reading the holy verses of the Qur'an in the Musabaqah Tilawatil Qur'an (MTQ). As for art that is not included in Islamic art, people know it with folk art. The categorization between Islamic and non-Islamic art is only conceptual, while at the practical level, sometimes there is a mix-up of elements that are characteristics of other categories.

Based on this categorization, the Islamic art of the song Macapat Qur'an was chosen as the object of this research. The main reason for choosing the Islamic art of the Macapat Koran song as the object of study is its uniqueness and distinctiveness. Therefore, it needs to be revealed so that it is known by the wider community, including the performance and the songs it performs [8]. Therefore, this study focused on the history, existence, and contribution of the Macapat Koran song art in building religious moderation in the Magetan regency.

\section{METHOD}

This research is qualitative descriptive research that wants to describe a social phenomenon about the traditional art of Tembang Macapat, whose content or content is composed of a translation of the Al-Qur'an.
There are three aspects studied in this study: the historical aspect of the birth of the Macapat Al-Qur'an song, the existence aspect of the Macapat Al-Qur'an song, and the innovation aspect of the Macapat AlQur'an song.

Data collection techniques used interviews, observations, document studies, and focus group discussions (FGD). Interviews were conducted to obtain data about the history of the birth of the Macapat Al-Qur'an song, the existence of the Macapat Al-Qur'an song, and how to build religious moderation through the art of the Macapat song. Observations were used to observe developing or chanting the Macapat Al-Qur'an, data about the situation and condition of the people of Pacalan Village, Plaosan District, Magetan Regency, East Java Province, Indonesia. The document study technique was used to collect data about documents in a manuscript or book of the Macapat Al-Qur'an written by Kyai RM. Suryoharyono and other documents in the form of news or information related to the performance of the song Macapat Al-Qur'an at the closing of the Musabaqah Tilawatil Quran (MTQ) in Magetan Regency. The Focus Group Discussion (FGD) technique was used to collect information on building religious moderation through art, including various information about the method. These factors influence it, its advantages and disadvantages, including a review of the art of Macapat Al-Quran from various perspectives, including the perspective of Islamic jurisprudence, art culture, education, tourism, and others.

Interpretation. After long-term creation and convention, dialect is a common heart symbol and handed down. It comes from the common national language but not precisely the same. The distinct regional characteristics deposit people's deep cultural genes in psychological character, contain rich human nature and human feelings. It is not only a tool of literature but also the object of literature itself, which constitutes a part of the cultural implication of works [8] [9] [10].

\section{FINDING AND DISCUSSION}

\section{1 History of Macapat Al-Quran in Magetan}

The history of the birth of composing the translation of the Al-Qur'an into a macapat song began with Kyai RM. Suryoharyono (caretaker of Pondok Pesantren Kembangsore, Pacalan, Magetan) with the Regent of Magetan at that time (Syihabuddin) ahead of the implementation of the East Java Provincial MTQ in Magetan in 1984. The discussion between 
these two figures took place at Kyai RM Suryoharyono's house when the regent of Syihabuddin visited there. Their conversation was quite warm and relaxed in a reasonably spacious pendapa house (interview with Suraji Saputra, 3 December 2019).

Following up on the conversation, Kyai RM. Suryoharyono ordered his santri named Suraji Saputra to compose a macapat song based on the essence of the translation of the Al-Qur'an. The order was given to Suraji Saputra because it was judged that he could carry out the order well. At first, Suraji Saputra objected to the order, but because it was the teacher's order or kyai to his students or students, he was unable to refuse. So, Suraji Saputra began to collect materials to start composing the macapat song, whose contents were sourced from the translation of the Koran. The time provided was concise, so Suraji Saputra had to work hard to complete it.

Suraji Saputra realized that this was not an easy job. On the one hand, a song composer must follow the rules in the song, especially the macapat song. These rules include the number of lines per stanza, the number of syllables per line, and the rhymes of each line. In addition, a composer of macapat songs must also understand the nature or character of the song. But, on the other hand, a composer of macapat songs must also understand the content of the message or essence of the translation of the Koran.

The work was then staged at the closing of the MTQ in Magetan. Suraji Saputra acts as a singer and singer and is accompanied by the strains of Javanese music in the form of a xylophone. The macapat song that is sung contains the message or essence of the letter of the Children of Israel. The music of the xylophone that floats faintly accompanying the strains of the macapat song is indeed a stunning combination. For Javanese people who can appreciate the meaning of the strains of the macapat song, they will feel a calm, relaxed, and peaceful heart that cannot be described in words [11] [12] [13].

This research focuses on a village on the slopes of Mount Lawu named Pacalan village. At a glance, the profile of this village can be stated that this village was formerly a village freed from taxes since it had an essential role for the Yogyakarta Sultanate. Around the middle of the 19th century, an envoy from the Sultanate of Yogyakarta named KRT Cokrodirono. He was sent by the consort of Sultan Hamengkubuwono II or Sultan Sepuh named Gambariah. Gambariah is the daughter of KRA. Purwodiningrat (regent of Magetan II) who was married by Sultan Hamengkubuwono II and became empress. Cokrodirono was asked to guard the grave of his parents (KRA. Purwodiningrat) and the mosque in that place.

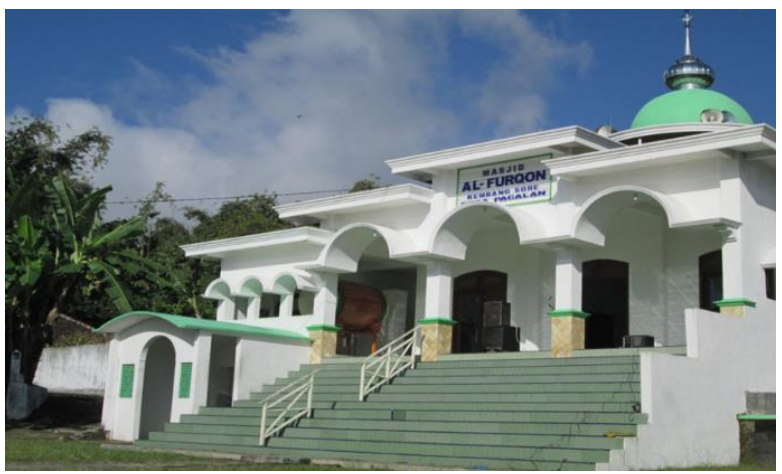

Figure 1. Al-Furqon mosque in Pacalan, Magetan, East Java (Source: Researcher collection, 2019)

The order was contained in a nawala (letter) written by the empress to Cokrodirono. The letter stated that the Pacalan village area was divided into four hamlets, namely Sangeng, Dokingkin, Geneng, and Pacalan hamlets. In addition, there was also a threat that if Cokrodirono did not carry out the order, Cokrodirono would suffer a disaster. Based on the letter, Pacalan Village was established as a fief village (desa perdikan/merdeka) of the Yogyakarta Sultanate government. Since then, it has also been determined that the village head is a descendant of Cokrodirono. Because Cokrodirono's descendants live in Pacalan Lor (north) and Pacalan Kidul (south), the leadership system is arranged alternately. The village head of Pacalan Lor descent, namely KRA. Mertowongso, KRA Sariwongso, RM. Parto Ngulomo, and RM. Partokusumo Imam Bardjah, while from Pacalan namely KRT. Cokrodirono, KRT. Darmosentono, RM. Surosudarmo, and RM. Suryoharyono. The determination of the status as a fief village lasted until 1962. Since that year, the status was abolished by the government of the Republic of Indonesia. As a result, the political system turned into an election instead of a determination based on heredity. Since then, the status of this village has been the same as other villages in the Magetan regency government.

The location of this village is on the slopes of Mount Lawu, so the air is quite remarkable, and the soil is fertile. Based on statistical data in 2014, the people's livelihoods are farmers (2,069 people) and farm laborers $(1,225$ people). The religious life of the community is quite conducive, with the majority of people being Muslims (4,958 people), and some of them are Christians (3 people) and Hindus (3 people). 


\subsection{The Existence of Macapat Quran in Magetan}

Macapat Qur'an is a macapat song whose contents are composed of a translation of the Qur'an. This Macapat Qur'an was composed by Suraji Saputra from Pait Hamlet, Buluharjo Village, Magetan. He is a student of Kyai RM. Suryo Haryono, the Kembang Afternoon Islamic Boarding School in Pacalan Village, Magetan. Suraji Saputra wrote this macapat song on the orders of Kyai RM. Suryo Haryono. He started writing the song ahead of the Musabaqah Tilawatil Qur'an in Magetan in 1984 [1].

Walisongo, Pakubuwana IV, and Ranggawarsita did the writing of the macapat song whose contents were sourced from the Koran. Walisongo, in carrying out Islamic da'wah, uses macapat songs to gain public sympathy. Pakubuwana IV also composed a macapat song based on the Koran. Likewise, the poet Ranggawarsita once composed a macapat song using messages in the Koran. The writing of this Koranic macapat song can be said to imitate the preaching pattern of Walisongo, Pakubuwana IV, and Ranggawarsita. Still, the form, content, and type of the macapat song composed are different from the previous work.

The Koranic Macapat song is a macapat song whose composition follows specific rules. The rules include the number of lines in each stanza or, the last vowel in each line, and the number of syllables in each line. This rule is binding on every macapat song, namely Maskumambang, Mijil, Sinom, Asmarandana, Gambuh, Dhandhanggula, Kinanthi, Pangkur, Megatruh, Durma, and Pucung. The composition of the song Macapat Qur'an by Suraji Saputra does not contain all types of songs but only the songs Dhandhanggula, Pangkur, Asmarandana, and Gambuh. It is due to his limited ability to compose songs (interview, 3 December 2019)

Each of these songs contains moral values, character, and instructions or guidelines about the primary behavior that humans must carry from birth to near death to achieve the glory of life in this world and the hereafter (Hascarya, 1979). Maskumambang (fetus floating in the mother's womb), Mijil (born), Sinom (youth), Asmarandana (time of making love), Gambuh (achieving compatibility between male and female), Dhandhanggula (time of becoming an adult human), Kinanthi ( the period of educating children), Pangkur (the period of holding principles and making priorities in life), Durma (giving charity), Megatruh (separating between spirit and body), and Pucung (died and worn pocong).
Table 1 The metrum of Javanese song (Macapat)

\begin{tabular}{|c|c|c|c|c|}
\hline No. & $\begin{array}{l}\text { Song } \\
\text { name }\end{array}$ & Line & Rhyme & $\begin{array}{l}\text { Syllable } \\
\text { per-line }\end{array}$ \\
\hline 1. & Mijil & 6 & $\mathrm{i}, \mathrm{a} / \mathrm{o}, \mathrm{e}, \mathrm{i}, \mathrm{i}, \mathrm{a} / \mathrm{o}$ & $\begin{array}{l}\text { 10,6,10,10, } \\
6,6\end{array}$ \\
\hline 2. & $\begin{array}{l}\text { Maskuma } \\
\text { mbang }\end{array}$ & 4 & $\mathrm{i}, \mathrm{a}, \mathrm{i}, \mathrm{a}$ & $12,6,8,8$ \\
\hline 3. & Sinom & 9 & $\begin{array}{l}\text { a/o,i,a/o,i,i,u, } \\
\text { a/o,i,a/o }\end{array}$ & $\begin{array}{l}8,8,8,87,8 \\
, 7,8,12\end{array}$ \\
\hline 4. & $\begin{array}{l}\text { Asmarad } \\
\text { ana }\end{array}$ & 7 & $\begin{array}{l}\text { i,a/o,a/o/e,a/ } \\
\text { o,a/o,u,a }\end{array}$ & $\begin{array}{l}8,8,8,8,7 \\
8,8\end{array}$ \\
\hline 5. & Gambuh & 5 & $u, u, i, u, a / o$ & $\begin{array}{l}7,10,12,8, \\
8\end{array}$ \\
\hline 6. & Kinanthi & 6 & U,i,a/o,i,a/o,i & $\begin{array}{l}8,8,8,8,8, \\
8\end{array}$ \\
\hline 7. & $\begin{array}{l}\text { Dhandha } \\
\text { nggula }\end{array}$ & 10 & $\begin{array}{l}\text { i,a/o,e,u,i,a/o, } \\
\text { u,a/o,i,a/o }\end{array}$ & $\begin{array}{l}10,10,8,7 \\
9,7,6,8,12 \\
7\end{array}$ \\
\hline 8. & Pangkur & 7 & $a / o, i, u, u, a / o, i$ & $\begin{array}{l}8,11,8,7,12 \\
, 8,8\end{array}$ \\
\hline 9. & Pocung & 4 & $\mathrm{u}, \mathrm{a} / \mathrm{o}, \mathrm{i}, \mathrm{a} / \mathrm{o}$ & $12,6,8,12$ \\
\hline
\end{tabular}

The following is an example of a Macapat Koran song [1][14] composed in the form of the Dhandhanggula song from Ayat Kursi: (dhandanggula song/ metrum $(10 \mathrm{i}-10 \mathrm{a}-8 \mathrm{e}-7 \mathrm{u}-9 \mathrm{i}-7 \mathrm{a}-6 \mathrm{u}-8 \mathrm{a}$ $-12 \mathrm{i}-7 \mathrm{a})$

(1) Allah iku Pangeran sejati,

datan ana kang pantes sinembah,

kajaba Panjenengane,

Maha Gesang satuhu,

sarta kang jumeneng pribadi,

tan nagntuk salaminya,

lan sare satuhu,

kagunganipun sadaya,

sagung kang gumelar ing langit lan bumi,

nenggih titah sadaya.

[God is true God,

none worthy of worship,

except him,

The one who is truly alive

as well as stand-alone

not sleepy forever,

and really don't sleep,

all belong to him,

all that is in heaven and earth, 
also all humans].

(2) Datan ana sagung janma iki, benjang kang bisa aweh syafaat, mung karana palilahe,

Allah pirsa sadarum,

lakunira ngarep lan mburi,

datan bisa uninga,

pra titah sadarum,

tumrape ngilmuning Allah,

mung karana karsaning Allah pribadi,

marang titah sadaya.

[None of these creatures,

tomorrow that can intercede,

only by His will,

Allah knows everything,

your behavior front and back,

no one can see,

all living beings,

on the knowledge of Allah,

only by His will,

to all beings.]

(3) Panguwasa lan ngilmuning Gusti, lan wariting jagad kabeh nggennya, ngreksa jagad saisine,

nggennya ngreksa puniku,

tan ngrekasa ing Allah yekti,

tumrap sagung prakara,

tan wonten kalimput,

wondene Allah punika,

tuhu Gusti kang Maha Luhur sejati,

lan Agung para marta

[God's power and knowledge,

and the state of the world in it,

in protecting the world and all that is in it,

it is not difficult for Allah,

over all affairs,

nothing is missed,

as for God,

Truly Almighty God, and very great].

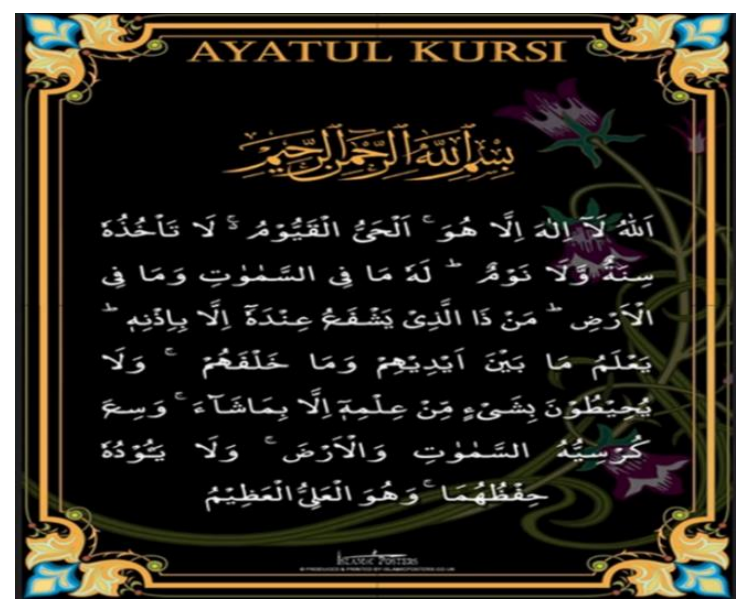

Figure 2. Ayat Kursi
The content and interpretation of Ayat Kursi in figure 2 are as described below. The first verse: "Allah, there is no god (who has the right to be worshiped) except Him Who lives eternally and continuously takes care of (creatures)." Allah is the greatest name of Allah the Exalted. Allah begins this verse by affirming the sentence of monotheism, which is the essence of Islamic teachings and all previous Shari'a. That is, there is no true deity to be worshiped except Allah. Consequently, you should not give any worship to other than Allah. Al-Hayyu and al-Qayyum are two of the al-Asma' al-Husna that Allah has. AlHayyu means One who lives by himself and forever. Al-Qayyum means that all need Him, and all cannot exist without Him. Therefore, Shaykh Abdurrahman as-Sa'di said that these two names denote all al-Asma' al-Husna.

Some scholars think that al-Hayyul Qayyum is the greatest name. This opinion and the previous one are the strongest on the issue of what is the greatest name of Allah, and all these names are in the second verse: "He neither sleeps nor sleeps." Glory be to Allah from all shortcomings. He is always watching and watching over everything. Nothing is hidden from him, and He is not heedless of His servants. Allah prioritizes the mention of sleepiness because sleepiness usually occurs before sleep. Some might say, "Just denying sleepiness is enough so there's no need to mention not sleeping; because if you just don't get sleepy, let alone sleep." However, Allah mentions both because it may be that (1) people sleep without falling asleep first, and (2) people can resist sleepiness but not sleep. So, denying sleepiness does not mean automatically denying sleep.

The third verse: "Him belongs what is in the heavens and the earth". This universe is the servant and property of Allah and is under His control. Therefore, no one can carry out a will except by the will of Allah.

The next verse: "none can intercede with Allah without His permission." To intercede means to intercede for others in bringing benefits or preventing harm. The essence of intercession with Allah is prayer. People also expect the intercession of the Prophet that means that they hope the Prophet prays for him too. There are special intercessions for the Prophet Muhammad, such as mediation for the start of reckoning in the hereafter, and intercession for the inhabitants of heaven so that the gates of heaven are opened for them. Some things are not special for the Prophet sallallaahu 'alahi wa sallam, such as mediation for those who have the right to go to hell. They are not included in it, and intercession is to be elevated to a higher degree in heaven. 
So, a Muslim can intercede for parents, children, relatives, or friends in the afterlife. However, mediation is only given to those who believe and die in a state of faith. Two things are required to get it, namely: 1). Allah's permission for those who intercede, and 2) The pleasure of Allah for those who are interceded. Therefore, one should not ask for intercession except Allah. In addition to praying, we should realize the conditions for mediation; by gaining the pleasure of Allah. Of course, by obeying Him, we carry out His commands as best we can and leave all His prohibitions.

The following line: "He knows what is before them and behind them." It argues that Allah's knowledge covers all creatures, whether existing in the past, present, or future. Allah knows what has been, is, and will happen, even what is destined not to exist, how it would have been if there had been. Therefore, Allah's knowledge is perfect.

The following line: "and they know nothing of Allah's knowledge except what He wills." No one knows Allah's knowledge, except what Allah teaches. Likewise, the knowledge of the essence and attributes of Allah. We have no way of assigning a name or attribute, except what He wills to be specified in the Qur'an and al-Hadith.

The next verse: "Allah's seat covers the heavens and the earth." Ibn Abbas radhiallahu 'anhu interpreted the chair by saying: Ayat Kursi is the place where the soles of Allah's feet are." (HR. al-Hakim no. 3116, judged authentic by al-Hakim and adz-Dzahabi). Ahlussunnah set these characteristics as determined by Allah and the Prophet sallallaahu 'alayhi wa sallam, according to the majesty and glory of Allah without likening them to the nature of creatures. This verse shows the magnitude of the seat of Allah and the magnitude of Allah. In a hadith, the Prophet sallallaahu 'alaihi wa sallam said: There are no seven heavens compared to a chair except like a ring of earrings placed in a clearing." (Narrated by Ibn Hibban no. 361, judged authentic by Ibn Hajar and al-Albani)

The following ayat is: "And Allah is not burdened with the care of both of them". A mother, of course, feels how tired it is to take care of the house alone. So likewise, a village head, sub-district head, regent, governor, or president manage the area they lead. However, this is not the case with Almighty Allah. The care of the heavens and the earth and their contents is very light for Him. Everything is small and straightforward before Allah.

"And He is Most High, Most Great." Allah has a high position, and His essence is at a height, namely above the sky (above the throne). In a hadith, the Prophet sallallaahu 'alahi wa sallam asked a slave girl: "Where is Allah?" He replied, "In the sky." The Prophet sallallaahu 'alaihi wa sallam asked, "Who am I?" He replied, "You are the Messenger of Allah." So, the Prophet sallallaahu 'alahi wa sallam said to his master (the slave girl's employer -ed), "Free her, for she truly believes!" (H. Muslim no. 537). Some people's belief that Allah is everywhere contradicts the Qur'an and al-Hadith. Likewise, Allah has a great position, and His essence is also great, as shown by the majesty of His chair in this verse [14].

Al-Qur'an, sung in murotal form, can also be used for psychological therapy. Complementary therapies in music and murottal therapy are believed effective because the songs and Quran can have a therapeutic effect through the mind and physiology of humans [2]. This Islamic art taught in this educational institution includes dances such as Kaili's local dance called momonte, qasidah songs, Arabic calligraphy that contains Quranic verses, Hadith, and Islamic poetry. In addition, various art instruments provided by this institution in supporting children's activities comprise guitar, rebana (tambourine), kerincing (triangle), and sound system [16]. The benefits of art gained by the children include giving lively entertainment to children, introducing Islam through art, and habituating them with Islamic and local cultures. In addition, art will become a way to sharpen instinct and teach Islam with the tenderness of art.

\subsection{Building Religious Moderation through Macapat Al-Quran}

Religious moderation is a priority program of the Ministry of Religion of the Republic of Indonesia. Religious moderation is made a priority program because of the importance of religious moderation amid the diverse and multicultural conditions of the Indonesian nation. In this context, religious moderation can be interpreted as a way or effort in religion that is not too extreme to the right that leads to radical or extreme left behavior that tends to be liberal, which considers all religions the same.

Religious moderation prioritizes tolerance within the internal and inter-religious sphere. Active tolerance to strengthen religious harmony always needs to be encouraged and strengthened to foster harmony in a pluralistic society. Abdurrahman Mas'ud stated that strengthening active tolerance or religious moderation is the right strategy in creating religious harmony in Indonesia. He said there were at least two significant policies to maintain religious harmony or moderation. First, empowering the community, religious groups, and religious leaders to solve the 
problems of religious harmony on their own. Second, providing guidelines (through relevant regulations and programs) in managing religious harmony [4]

In line with that, empowering the community, religious groups, and religious leaders in solving their religious harmony problems can be done by strengthening arts and culture in that community [17]. Because art and culture do not differentiate people according to religion and cultural arts do not divide society based on religion. Cultural arts can be a powerful medium to maintain religious harmony.

Macapat Qur'an, as a product of Javanese cultural arts, can be optimized for its benefits to establishing internal and inter-religious harmony. The trick is to implement the messages of the Koran, which are realized in the form of macapat songs. Moreover, the messages of the Koran, which are composed in the form of macapat songs, provide a broader and universal space, for example messages of love, help, mutual assistance, and so on, to involve groups or people of different religions.

Macapat Qur'an gives a touch to the dimensions of the heart or human feelings. A touch of the heart filled with tenderness is expected to give birth to an attitude of empathy and sympathy for others regardless of religion, ethnicity, race, and class. Moreover, this touch on the heart is expected to give birth to a tolerant attitude towards other religious people and people of the same religion with different views and understandings.

Macapat Qur'an cultural art can also be used to create a conducive atmosphere of religious life. Religious messages contained in the lyrics of the Macapat Qur'an can be used as material to strengthen the deepening and appreciation of religion and the practice of religion that supports the development of internal and inter-religious harmony.

Doing the deepening of implementing spiritual values through the cultural arts of Macapat Qur'an can strengthen and strengthen religious life and strengthen tolerance for humanity based on religious values. Implementable spiritual values that can be extracted from the Macapat Qur'an are vibrant so that they can be developed to build and create harmony in this religious and pluralistic society.

\section{CONCLUSION}

In this closing section, conclusions can be drawn from the above description. Building religious moderation through the art of the Macapat Qur'an can be done by implementing the messages in the Qur'an, which are embodied in religious life. Messages about love, compassion, and other universal values sourced from the Qur'an can be used to strengthen the harmony that has been built in the community.
Macapat Qur'an gives a touch to the dimensions of the heart or human feelings. A touch of the heart filled with tenderness is expected to give birth to an attitude of empathy and sympathy for others regardless of religion, ethnicity, race, and class. Moreover, this touch on the heart is expected to give birth to a tolerant attitude towards other religious people and people of the same religion with different views and understandings.

Religious moderation prioritizes tolerance within the internal and inter-religious sphere. Active tolerance to strengthen religious harmony always needs to be encouraged and strengthened to foster harmony in a pluralistic society.

\section{ACKNOWLEDGMENTS}

The researcher would like to thank all those who have helped write this article. Special thanks go to Mr. Suryoharyono and Mr. Suraji Saputra for supporting the research. He also expresses gratitude to the head of the Ministry of Religion, Magetan Regency, East Java, Indonesia.

\section{REFERENCES}

[1] RM. S. Haryono, "Ayat Kursi Awujud Sekar Dhandhanggula", Magetan: Pesantren Kembang Sore Pacalan. 1984,

[2] Herdiman, and Ilbert. The Effect of Murottal and Music Therapy on Reducing Blood Pressure in Palimanan Climbon,2019, 10.18502/kls.v4i13.5341

[3] M. A. C. T. Noh, A. H. Razak, K. A. Suhid, and Asmawati. "The study of Quranic teaching and learning: United Kingdom experience". Mediterranean Journal of Social Sciences, vol. 5 no. 16, pp. 313-317. 2014.

[4] K. Setiawan, "Strategi moderasi antarumat beragama" July $26^{\text {th }}, 2018$.

https://www.nu.or.id/post/read/93454/strategimoderasi-antarumat-beragama.

[5] T. R. Rohidi, "Kesenian dalam Pendekatan Kebudayaan”, Bandung: STSI, 2000.

[6] R. M. Koentjaraningrat, "Kebudayaan, mentalitas, dan pembangunan: bungarampai". Gramedia Pustaka Utama, 1994.

[7] M. Thohir, "Multi-kulturalisme agama, budaya, dan sastra". Gigih Pustaka Mandiri, 2013.

[8] X. Gao, "The Influence of the Intangible Cultural Heritage on the Local Novels of Sichuan”, 2016. https://doi.org/10.2991/snce-16.2016.8 
[9] Y. Yi, "Minority Cultural Heritage: the Aesthetic Reproduction in Consumption Age". Journal of Luoyang Normal University, vol. 4, no. 4, 2013

[10] C. Maags, \& H. Holbig, "Replicating Elite Dominance in Intangible Cultural Heritage Safeguarding: The Role of Local GovernmentScholar Networks in China", International Journal of Cultural Property, vol. 23 no. 1, pp. 71-97, 2016.

[11] D. K. Azis, ”Akulturasi Islam dan Budaya Jawa”. Fikrah, vol. 1, no. 22013. http://journal.stainkudus.ac.id/index.php/Fikrah/ $\underline{\text { article/view/543 }}$

[12] U. Sumbulah, ’Islam Jawa dan Akulturasi Budaya", el Harakah, vol. 14, no.1, pp.51-68, 2012

[13] S. M. Amin, ’Ilmu Dakwah", Jakarta: Hamzah, 2009.

[14] G. S. Hastjarjo, "Macapat, Monograf, Proyek Pengembangan Institiut Kesenian Indonesia (IKI)", , Surakarta, 1980

[15] A. Burhanuddin, “Tafsir ayat kursi” 2015. https://www.ayat-kursi.com/2015/04/tafsir-ayatkursi.html

[16] N. F. Rahmayani, F. Ahsan, and M. Nur, "Seni sebagai Media Dakwah pada Anak Usia Dini” Mishbah: Jurnal Ilmu Dakwah dan Komunikasi, vol.12, no. 2, pp. 271-292, 2017.

[17] L. Li, "Intangible Cultural Heritage and New Communities of Knowledge Production: An analysis based on Village Studies." Positions: East Asia Cultures Critique, vol. 22, no. 3, pp. 721-740. 2014. 